efficiency. In conclusion, Prof. Bernal expressed the belief that the undifferentiated way of dealing with things which is characteristic of the scientific method, will, given good organization, build up a far better war machine than the one we have against us.

\section{The War and Nesting Birds}

The most interesting effect of the War upon nesting birds in Great Britain has been the attraction of the black redstart (Phonicurus ochrurus gibraltariensis) to nest in the air-raid ruins of some English towns. Until the War, this was one of the rarest British nesters, although a regular winter visitor, but on the Continent where it is a familiar town bird it shows a partiality for ruins and it would be interesting if it becomes a commoner British resident in this unexpected way. In 1923 this bird was first noted nesting in Great Britain in a southern county and in 1936 it began nesting in Cambridge. In 1940 and 1941 it nested in the city area of London and a considerable number of London Natural History Society observers watched the birds. Another influence upon nesting birds has been the military disturbance of many coastal and rural haunts, the felling of woods and the draining of marshland. Another rare British nester, the black-necked grebe (Podiceps nigricollis nigricollis), was under observation by the Merseyside Naturalists' Association this year at a new nesting site at Abbot's Moss, the third it has used in Cheshire. In Anglesey there was a considerable increase in the number of roseate terns nesting at Llandwyn island, where between sixty and seventy pairs nested this year with Sandwich terns, etc., and new terneries, possibly an overflow of this species, were made at Malldraeth Point and on Ynys Ferrig rocks in Rhosneigr Bay. The kite has, however, maintained its nesting haunt in the valleys of mid-Wales and the black guillemot its recent habitat on the Cumberland cliffs at St. Bees Head.

\section{The British Association}

The report of the British Association for 1942 (Vol. 2, No. 6) is now available (price 5s.), and contains the full text of the papers given at the conference on European agriculture held by the Division for the Social and International Relations of Science in London during March 20-21, 1942. Problems in postwar reconstruction was the subject of discussion at the conference, the papers falling into four main sections: measures for reconstruction, economic and kindred problems, the future betterment of European farming and problems of peasant farming. The contributors, many of whom came from occupied countries and represented very different types of farming, were remarkably in agreement as to the causes of pre-war agricultural problems and the main lines upon which future reconstruction should be based, namely, the development of small-scale peasant farming, concentrating primarily on livestock, fruit and vegetable production in order to raise the standard of living and nutrition.

In addition, the report contains an article by Sir Henry Lyons on the work of the International Research Council (now the International Council of Scientific Unions) which will be of special interest to those concerned with the possibility of increasing collaboration in science through some form of standing organization, and an account of the peace-time activities of the British Association by its president, Sir Richard Gregory.

\section{The Study of Soils}

The Cantor lectures delivered at the Royal Society of Arts by Dr. B. A. Keen in January and February on soil physics, soil cultivation, and cultivation and crop yields have been published in the Society's Journal $(40,545 ; 1942)$. The study of soil physies is relatively new, and only within the last twenty or thirty years has this side of agricultural practice been placed on a sound theoretical basis, The substitution of the pore-space theory in place of the capillary-tube hypothesis as an explanation of the water relations within the soil has, for example, led indirectly to improvements in certain practices in irrigation areas and in land drainage. The effectiveness of different types of cultivation and the influence of weather on the formation of tilth can now be measured by studying the resulting soil structure, and both the design, performance and use of imple. ments can accordingly be put on a more scientific basis. As regards the effect of cultivation on crop yield, the traditional views held in Great Britain are called in question. Experiments on certain soils have shown no special benefits to the crop from additional or increased depth of cultivation, and since cheap labour is no longer available and every mechanized operation costs fuel and oil, a plea is made for similar investigations to be carried out in widely different districts, so that reliable information of a more general nature on such an important economic question may be fortheoming.

\section{Canadian Water Supplies}

Erght years ago the Canadian Department of Mines and Reservoirs began a survey of all the water supplies in Canada, with the view of determining the mineral and other content of the industrial and domestic water of the Dominion. The final results of this survey are now published in "Industrial Waters of Canada", by H. A. Leverin (Ottawa : King's Printer. Pp. 112. 25 cents). The investigation involved the determination of suspended matter, silica, iron, calcium, magnesium, sulphate, alkalis, potassium, bicarbonate, free carbonic acid, chloride, nitrate, oxygen, hydrogen-ion and colour. The report discusses the origin and distribution of these impurities and their importance in many industrial processes. It appears that distilled water is necessary not only in the manufacture of chemicals or drugs but also in the manufacture of ice, storage batteries, yeast, aerated waters and the plating of mirrors. In the paper and pulp industry, in the making of such varied commodities as textiles, soap and ice, and in brewing, distilling, baking, tanning, canning, etc., the nature and amount of the impurities are of much significance. The processes used in the investigations are fully described, and the publication contains tabulated analyses of surface and civic water supplies and maps showing the hardness of town water supplies throughout the Dominion.

\section{Tuberculosis in El Salvador}

The March issue of the Boletin de la Oficina Sanitaria Panamericana contains an interesting paper by Dr. Rafael Vega Gomez, head of the Tuberculosis Department and ex-director of health, El Salvador, on the control of tuberculosis in his country. The campaign against the disease began in 1928 with the foundation of a National Tuberculosis Sanitorium, in which the number of beds has risen from 30 to 105 . Previously the only accommodation for tuberculosis 